Article

\title{
Gene Polymorphisms of TLR4 and TLR9 and Haemophilus influenzae Meningitis in Angolan Children
}

\author{
Elina Tenhu ${ }^{1}$, Johanna Teräsjärvi ${ }^{1}$, Manuel Leite Cruzeiro ${ }^{2}$, Okko Savonius $^{3}$, \\ Emilie Rugemalira ${ }^{3}$, Irmeli Roine ${ }^{4}$ (D) Qiushui He ${ }^{1,5, *}$ and Tuula Pelkonen ${ }^{2,3}$ (D) \\ 1 Institute of Biomedicine, Research Center of Infections and Immunity, University of Turku, \\ 20520 Turku, Finland; elpate@utu.fi (E.T.); johter@utu.fi (J.T.) \\ 2 Hospital Pediátrico David Bernardino, Luanda 00000, Angola; mcruzeiro1@gmail.com (M.L.C.); \\ tuulapelkonen@hotmail.com (T.P.) \\ 3 Children's Hospital, Pediatric Research Center, University of Helsinki, Helsinki University Hospital, \\ 00029 Helsinki, Finland; okko.savonius@helsinki.fi (O.S.); emilie.rugemalira@helsinki.fi (E.R.) \\ 4 Faculty of Medicine, University Diego Portales, Santiago 8370109, Chile; irmeli.roine@gmail.com \\ 5 Department of Medical Microbiology, Capital Medical University, Beijing 100069, China \\ * Correspondence: qiushui.he@utu.fi; Tel.: +358-50-472-2255; Fax: +358-2-333-8413
}

Received: 3 August 2020; Accepted: 18 September 2020; Published: 21 September 2020

check for updates

\begin{abstract}
Bacterial meningitis (BM) is a severe disease caused by various bacterial pathogens. Toll-like receptors (TLRs) protect humans from invading pathogens. In this study, we determined whether single nucleotide polymorphisms (SNPs) of TLR4 and TLR9 are associated with susceptibility to and outcome of BM in Angolan children. Samples were taken from 241 patients and 265 age-matched ethnic controls. The SNPs TLR4 rs4986790 (896A > G) and TLR9 rs187084 (-1486T > C) were determined by high-resolution melting analysis (HRMA). The frequency of variant genotypes in TLR4 was significantly higher in patients with Haemophilus influenzae meningitis than controls (odds ratio (OR), 2.5; 95\% confidence interval $(\mathrm{CI}), 1.2-5.4 ; p=0.021$ ), whereas the frequency of variant genotypes in TLR9 was significantly lower in patients with $H$. influenzae meningitis than controls $(\mathrm{OR}, 0.4 ; 95 \% \mathrm{CI}, 0.2-0.9 ; p=0.036)$. No such differences were found with other causative pathogens, such as Streptococcus pneumoniae and Neisseria meningitidis. At the time of discharge, patients with meningitis caused by Gram-negative bacteria who were carriers of variant TLR4 genotypes had a higher risk of ataxia (OR, 12.91; 95\% CI, 1.52-109.80; $p=0.019)$ and other neurological sequelae $(\mathrm{OR}, 11.85 ; 95 \% \mathrm{CI}, 1.07-131.49 ; p=0.044)$ than those with the wild-type TLR4 genotype. Our study suggests an association between $H$. influenzae meningitis and genetic variation between TLR4 and TLR9 in Angolan children.
\end{abstract}

Keywords: TLR4; TLR9; gene polymorphisms; meningitis; Haemophilus influenzae; HRMA; children; Angola

\section{Introduction}

Bacterial meningitis (BM) is a life-threatening infectious disease. Even with early diagnosis and proper treatment, the fatality rate of BM ranges from 5\% to 10\% in developed countries and up to $50 \%$ in low-and middle-income countries. It is estimated that approximately 1-2 million cases of BM occur a year [1], with neonates particularly susceptible. Survivors of meningitis are at an increased risk of neurological sequelae, such as learning and behavioral disorders, deafness, paresis, and severe encephalopathy [2]. The most common prerequisite for BM is nasopharyngeal colonization and bacteremia, where bacteria can spread from blood to cerebrospinal fluid (CSF). The pathogens 
can infect the central nervous system (CNS) by crossing the blood-CSF barrier, invading the CSF directly through a skull fracture, or from a focal infection (e.g., the nasal sinuses) to the subarachnoid space [2-4].

BM is caused by various bacteria such as Streptococcus pneumoniae, Neisseria meningitidis, and Haemophilus influenzae. H. influenzae is still one of the most common causes of BM in non-industrialized countries. This is due to the lack of effective vaccinations, which have virtually eliminated $H$. influenzae type b meningitis in industrialized countries [5]. Both $H$. influenzae and N. meningitidis are Gram-negative bacteria carried in the nasopharynx. H. influenzae is a common causative agent of BM in young children [6,7]. Around $10 \%$ of people, mostly school-aged children, carry N. meningitidis in their nasopharynx, and N. meningitidis is the main cause of BM in children and young adults. N. meningitidis causes epidemics, particularly in sub-Saharan Africa (the "meningitis belt"). Pneumococcal nasopharyngeal carriage is common in the general population and affects people of all ages. S. pneumoniae causes the most severe disease in both young and old people [2,8-10].

Routine immunizations in Angola include the pentavalent vaccine (i.e., diphtheriatetanus-pertussis (DTP), hepatitis B, and H. influenzae type b), which was introduced in 2006, and the 13-valent pneumococcal vaccine (PCV13), which was introduced in 2013 [11]. Both are administered at 2, 4, and 6 months of age. The current estimates of the coverage of three doses of DTP vaccine in children in Angola range from 48\% to 84\% [12,13], while estimates for PCV13 vaccination rates range from $59 \%$ to $82 \%[11,12]$.

The number of children with BM has been decreasing in the Paediatric Hospital of Luanda following the introduction of routine childhood pentavalent vaccination in 2006. In particular, the number of BM cases due to H. influenzae type $b$ has dropped by $86 \%$ in the Paediatric Hospital [14]. In 2004, before the use of PCV13 in Angola, there were 93 cases of pneumococcal meningitis identified in children in this hospital; however, our one-year study found 43 cases of pneumococcal meningitis, indicating a large decline of BM caused by S. pneumoniae in the post-PCV13 period [5].

Pathogen-sensing Toll-like receptors (TLRs) are key components of innate and adaptive immunity. To date, ten TLRs have been identified in humans (i.e., TLR1 to TLR10). TLR4 is expressed on the cell surface and recognizes the lipopolysaccharides (LPSs) of H. influenzae and N. meningitidis, as well as pneumolysin produced by S. pneumoniae [15]. TLR4 requires the adaptor protein MD2 to bind to the lipophilic part of LPSs, which activates intracellular signaling and leads to a host immune response to invading pathogens [16-19]. TLR9 is localized in the endosomal compartments of cells. It is specialized in detecting bacterial un-methylated single-stranded DNA-more specifically, unmethylated cytosine-guanosine-containing oligonucleotide (CPG-DNA). TLR9 requires the DNA-degrading enzyme DNase to sense single-stranded DNA $[16,18,20]$. It has been observed that S. pneumoniae, H. influenzae, and N. meningitidis can activate species-specific patterns of TLR4 and TLR9 [21].

Genetic factors are major determinants of human susceptibility to infectious diseases. A common type of genetic variation is single-nucleotide polymorphisms (SNPs), which, in immune genes such as TLRs, are involved in the susceptibility, severity, and outcome of different bacterial and viral infections [22]. Two well-studied functional SNPs of TLR4 (rs4986790) and TLR9 (rs187084) were included in this study. The polymorphism of TLR4 Asp299Gly impairs TLR4-mediated LPS signaling and results in decreased LPS-stimulated NFKB activity [23]. In our previous study, we found that this polymorphism increases the risk of nasopharyngeal colonization of H. influenzae and Moraxella catarrhalis in healthy Finnish children [24]. This polymorphism is also associated with septic shock [25], respiratory syncytial virus (RSV) bronchiolitis [26], sepsis [27], and urinary tract infection (Table 1). However, previous studies have also shown that the TLR4 polymorphism does not increase the risk of meningococcal or pneumococcal diseases such meningitis or sepsis [28-30]. The polymorphism TLR9 rs187084 is associated with streptococcal infections and tuberculosis, as well as autoimmune disorders and cancers [31-33]. 
Table 1. Functions of the analyzed single-nucleotide polymorphisms (SNPs) and allele frequencies in the African population.

\begin{tabular}{|c|c|c|c|c|c|}
\hline Target & SNP ID & Location & $\begin{array}{l}\text { Allele } \\
\text { Frequency in } \\
\text { the African } \\
\text { Population }\end{array}$ & $\begin{array}{c}\text { Allele } \\
\text { Frequency in } \\
\text { this Study }\end{array}$ & $\begin{array}{l}\text { Potential Effect and } \\
\text { Reported Associations }\end{array}$ \\
\hline TLR4 & rs 4986790 & $\begin{array}{c}\text { Chromosome } 9 \\
\text { In gene } \\
896 \mathrm{~A}>\mathrm{G}\end{array}$ & $\begin{array}{l}\text { A: } 0.93 \\
\text { G: } 0.07\end{array}$ & $\begin{array}{l}\text { A: } 0.91 \\
\text { G: } 0.09\end{array}$ & $\begin{array}{l}\text { Diminished responsiveness: } \\
\text { M. catarrhalis and } \\
\text { H. influenzae, pneumococcal } \\
\text { and meningococcal } \\
\text { infections, septic shock, } \\
\text { and respiratory syncytial } \\
\text { virus (RSV) }\end{array}$ \\
\hline TLR9 & rs187084 & $\begin{array}{c}\text { Chromosome } 3 \\
\text { Promoter area } \\
-1486 \mathrm{~T}>\mathrm{C}\end{array}$ & $\begin{array}{l}\mathrm{T}: 0.71 \\
\mathrm{C}: 0.29\end{array}$ & $\begin{array}{l}\mathrm{T}: 0.73 \\
\mathrm{C}: 0.27\end{array}$ & $\begin{array}{l}\text { Associated with } \\
\text { autoimmune disorders and } \\
\text { cancers, RSV, Acinetobacter } \\
\text { baumannii, tuberculosis, } \\
\text { and streptococcal infections }\end{array}$ \\
\hline
\end{tabular}

There are other TLR4 and TLR9 SNPs that are associated with BM. In one study, it was found that the carriage of one or both mutant alleles in TLR4 896A > G and TLR9-1237 increases the risk of hearing loss in BM survivors. Another study found that BM patients who carried the minor allele T of TLR9 (rs352140) developed seizures more often than those without. It has also been reported that there is an association between TLR9 SNPs and susceptibility to BM, specifically meningococcal meningitis. Although an association between the TLR9 polymorphism rs187084 and BM has not yet been described, previous studies with other TLR9 polymorphisms indicate that this polymorphism may also play a role in BM susceptibility or outcome [3,34,35].

Thus, our goal was to identify the functional gene polymorphisms of TLR4 and TLR9 that affect the susceptibility to and severity and outcomes of BM in Angolan children.

\section{Materials and Methods}

\subsection{Subjects}

This study was a part of two prospective randomized clinical trials of children with BM in the Luanda Children's Hospital (Hospital Pediátrico David Bernardino) Luanda, Angola. The studies were approved by the Luanda Children's Hospital ethics committee. We assessed all children aged 2 months to 15 years presenting with signs suggestive of BM. A child was enrolled if their CSF appeared cloudy, was positive by Gram staining, or showed $>50$ leukocytes $/ \mathrm{mm}^{3}$. The exclusion criteria included previous neurological abnormalities or hearing impairment, immunosuppression except for HIV infection, active tuberculosis, known hepatic disease, or pre-treatment with more than one dose of parenteral antibiotic. The patients were included in the study after informed consent was provided by their guardians $[36,37]$. Oral informed consent was also obtained from the guardians of the controls.

The study cohort consisted of 241 children with confirmed BM, children with compatible symptoms and signs of BM and a positive CSF Gram stain, latex agglutination, culture, or PCR or a positive blood culture, and of whom a filter paper blood sample was available. The median age was 15 months (interquartile range (IQR) 6, 43; range 1-161 months). Of these children, 47\% ( $n=114)$ were females and $53 \%(n=127)$ males. The detailed information of the patients is shown in the Table 2 , and numbers less than 241 refer to only those whose information was available. The diagnosis was made by the attending physician, and the diagnostic criteria have been described previously [38]. The control group consisted of 265 Angolan children with no history of BM, and with no active infection. The median age of the control group was 66 months (IQR 42, 114; range 0-186 months). The gender of the control group was registered in 191 cases; $37 \%(n=71)$ were female and $63 \%(n=120)$ were male. The control 
samples were collected after a Sunday service $(n=72)$, at other pediatric wards $(n=74)$, at the surgery ward $(n=18)$, at surgery outpatient visits $(n=59)$, or at vaccination visits $(n=42)$. The patients were enrolled from 2005 to 2008 and from 2012 to 2017, and the control group children were enrolled in 2008 and 2017.

Table 2. Background, clinical, and laboratory data of patients.

\begin{tabular}{|c|c|c|c|c|}
\hline Characteristics & $\begin{array}{c}\text { Total } \\
\text { Subjects }\end{array}$ & $N(\%)$ & $\begin{array}{c}\text { Value } \\
\text { Distribution }\end{array}$ & Range \\
\hline Age in months, median (IQR) & 241 & - & $15(6,43)$ & $1-161$ \\
\hline Weight (kg), median (IQR) & 241 & - & $9(6.8,12.7)$ & $3.6-36$ \\
\hline \multicolumn{5}{|l|}{ Clinical features } \\
\hline Length of hospital stay in days, median (IQR) ${ }^{3}$ & 158 & - & $12(10,36.05)$ & $6-63$ \\
\hline Poor general condition & 238 & $142(60 \%)$ & - & - \\
\hline Convulsion in hospital & 235 & $155(66 \%)$ & - & - \\
\hline Altered consciousness during admission & 237 & $166(70 \%)$ & - & - \\
\hline Additional focus of infection present & 232 & $69(30 \%)$ & - & - \\
\hline Fatal outcome & 241 & $63(26 \%)$ & - & - \\
\hline Severe neurological sequelae at discharge & 177 & $24(14 \%)$ & - & - \\
\hline \multicolumn{5}{|l|}{ Laboratory tests, median (IQR) } \\
\hline $\mathrm{CRP}(\mathrm{mg} / \mathrm{L})$ & 207 & - & $161(128,161)$ & $7-340$ \\
\hline Glucose in CSF (mg/dL) ${ }^{4}$ & 233 & - & $10(5.5,19.55)$ & $0.5-270$ \\
\hline Protein in CSF $(\mathrm{mg} / \mathrm{dL})^{4}$ & 118 & - & $201.15(136.2,269)$ & $10.2-1806$ \\
\hline Leukocytes in CSF $\left(/ \mathrm{mm}^{3}\right)^{4}$ & 241 & - & $1560(414.5,3590)$ & $8-32,400$ \\
\hline Blood leukocytes $(/ \mu \mathrm{L})$ & 182 & - & $15.3(10.2,21.4)$ & $1.23-57$ \\
\hline MMP-8 in CSF (ng/mL) & 92 & - & $854.2(250,1220)$ & $3.74-3560$ \\
\hline
\end{tabular}

\footnotetext{
1 The total number of subjects was 241; numbers less than 241 refer only to those whose information was available.

2 Axillary temperature, fever if $\geq 38.0^{\circ} \mathrm{C} .{ }^{3}$ The length of the hospital stay excludes patients with fatal outcome.

${ }^{4}$ Measured at admission. IQR, interquartile range (lower, upper); SD, standard deviation; CRP, C-reactive protein; CSF, cerebrospinal fluid; MMP-8, matrix metalloproteinase-8.
}

\subsection{Laboratory Tests, Clinical Findings, and Severity Factors of BM}

Microscopic examination, leukocyte counts, and glucose, matrix metalloproteinase-8 (MMP-8), and protein concentration measurements were performed for CSF specimens taken at admission. CSF was cultured on blood and chocolate agar plates and bacteria were identified by Gram stain or standard bacteriological phenotypic methods. When available, a latex agglutination test (Pastorex Meningitis, Bio-Rad Laboratories Inc., Marne-La-Coquette, France) was conducted if $>100$ leukocytes $/ \mathrm{mm}^{3}$ were present and bacterial culture was negative. Whenever possible, the remaining CSF sample was stored at $-80{ }^{\circ} \mathrm{C}$ and shipped for PCR identification to the National Institute of Health, Lisbon, Portugal, or later to the Centre for Respiratory Diseases and Meningitis (CRDM), National Institute for Communicable Diseases (NICD), Johannesburg, South Africa [37]. Concentrations of MMP-8 were determined with a time-resolved immunofluorometric assay (Medix Biochemica, Espoo, Finland).

In a previous study in the Paediatric Hospital of Luanda, Pelkonen et al. identified prognostic factors for poor outcomes in BM [5]. In this study, we compared the genotype distributions of TLR4 and TLR9 between the previously identified prognostic factors for poor outcomes in BM. The studied laboratory variables were levels of glucose, protein, leukocytes, and MMP-8 in CSF at admission. In addition, the highest level of C-reactive protein (CRP) and leukocytes in blood were analyzed. Additionally, the following factors were assessed: Poor general condition, level of consciousness, convulsions, and Glasgow and Blantyre coma scores at admission. In addition, neurological sequelae 
(other than ataxia), deafness, blindness, other focuses of infection during hospital stay, and fatal outcomes were analyzed.

\subsection{DNA Isolation}

Blood samples for the genetic studies of the BM patients $(n=241)$ and the first set of controls $(n=74)$ were collected with a dried blood spot (DBP) collection card (PerkinElmer 226 Sample Collection Device, PerkinElmer, Waltham, MA, USA), as these patients had blood collected for other purposes as well. Later, the second control set of DNA samples $(n=191)$ were taken from healthy individuals with SK-1S DNA buccal swabs (Isohelix, Harrietsham, Kent, UK) to avoid pain in sampling.

Genomic DNA was extracted with the QIAamp ${ }^{\circledR}$ mini DNA extraction kit (Qiagen, Hilden, Germany) according to the manufacturer's protocol for extracted genomic DNA. DNA concentrations were determined by a spectrophotometer (NanoDrop 1000, Thermo Scientific, Waltham, MA, USA). The entire eluted DNA sample was stored at $-20^{\circ} \mathrm{C}$ for further examination.

\subsection{Genotyping}

TLR4 896A > G (rs4986790) and TLR9-1486T > C (rs187084) were determined by high-resolution melting analysis (HRMA). The analyses were performed using LightCycler 480 version 5.1 (Roche, Basel, Switzerland) with a SensiFAST HRMA melting master kit (Bioline, London, UK). The method for TLR4 rs4986790 genotyping has been published in detail previously [39].

The primers for TLR4 rs4986790 (forward 5'-ACCATTGAAGAATTCCGATTAGCA-3', reverse 5'-CCAGGGAAAATGAAGAAACATTTG-3') and for TLR9 rs187084 SNP (forward 5'-TTATTCCCCTGCTGGAATGTCA-3' , reverse 5'-CTGTACTGGATCCTGGGGATG-3') were designed with the Primer-BLAST design tool (National Center for Biotechnology Information (NCBI), U.S. National Library of Medicine, Bethesda, MD, USA) and were ordered from Sigma-Aldrich (Saint Louis, MO, USA). Amplicon sizes were $95 \mathrm{bp}$ (TLR4) and $72 \mathrm{bp}$ (TLR9).

In each reaction, the volume was $20 \mu \mathrm{L}$ and consisted of $3 \mu \mathrm{L}$ of genomic DNA (approximately $8 \mathrm{ng} / \mu \mathrm{L}$ ) and $17 \mu \mathrm{L}$ of master mix, including $10 \mu \mathrm{L}$ of melting master dye and $0.2 \mu \mathrm{M}$ of forward and reverse primers. The master mix provided a final concentration of $3 \mathrm{mM}$ of $\mathrm{MgCl}_{2}$. The HRMA reactions were run at $95{ }^{\circ} \mathrm{C}$ for $10 \mathrm{~min}$, followed by 44 cycles of amplification at $95^{\circ} \mathrm{C}$ for $10 \mathrm{~s}$, at $60^{\circ} \mathrm{C}$ for $10 \mathrm{~s}$, and at $72^{\circ} \mathrm{C}$ for $15 \mathrm{~s}$. After PCR, the final melting cycle conditions were outlined by LightCycler: First heating to $95^{\circ} \mathrm{C}$ and holding for $1 \mathrm{~min}$, followed by cooling to pre-hold temperature $\left(40^{\circ} \mathrm{C}\right)$. The melting interval for collecting fluorescence was set from 60 to $95^{\circ} \mathrm{C}$ (a ramp rate of $\left.0.02{ }^{\circ} \mathrm{C} / \mathrm{s}\right)$. In each run, three DNA samples with known (sequenced) genotypes of TLR4 (rs4986790) and TLR9 rs187084 were used as controls.

Additionally, all samples with an atypical HRMA difference curve or melting peak were analyzed by Sanger sequencing in the Finnish Institute for Molecular Medicine (FIMM), Helsinki, Finland.

\subsection{Statistical Analyses}

Statistical analyses were performed using the JMP Pro software for Windows, version 14 (SAS Camous Drive, Cary NC, USA) and IBM SPSS Statistics for Windows, version 25 (IBM Corp., Armonk, NY, USA). Categorical variables are described using numbers $(n)$ and percentages $(\%)$ and bivariate analyses were performed with Fisher's exact test. Continuous data are described by using means and 95\% confidence intervals (CIs) or medians and IQRs as appropriate. SNP data and continuous data were compared using a Mann-Whitney $U$ test if the data were not normally distributed. Multivariate analysis (i.e., binominal logistic regression analysis) was performed for the clinical features if $p<0.05$. Poor general condition, convulsions during admission, and weight below two standard deviations (SDs) were used as covariates. A $p$-value of $<0.05$ was considered statistically significant. A Hardy-Weinberg (HWE) test was used to calculate the observed genotype distribution in the control population. The differences in the numbers of patients are due to missing or non-determined data. 


\section{Results}

\subsection{Detection of Pathogens and Laboratory Values}

Bacterial etiology was confirmed from all 241 BM cases. Of these, 136 (56\%) were caused by Gram-positive bacteria and 105 (44\%) by Gram-negative bacteria. The bacterial distribution is presented in Figure 1. The three most common pathogens identified were S. pneumoniae $(n=108$, $44.8 \%), N$. meningitidis $(n=43,17.8 \%)$, and $H$. influenzae $(n=38,15.8 \%)$. The overall case fatality rate was $26 \%(n=63)$. The highest fatality rate was $34 \%(n=37)$ in pneumococcal meningitis, whereas the lowest fatality rate was $5 \%(n=8)$ in meningococcal meningitis.

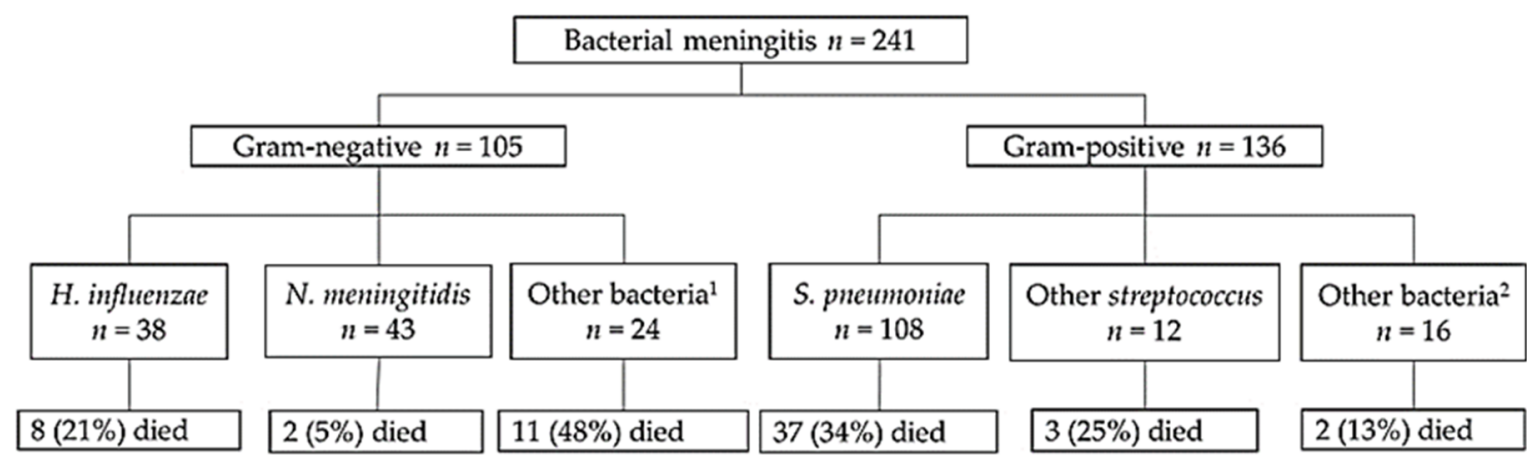

Figure 1. Distribution of the pathogens in the study population. ${ }^{1}$ Salmonella spp. $(n=5)$, Proteus spp. $(n=6)$, Citrobacter freundii $(n=2)$, Escherichia coli $(n=2)$, Klebsiella spp. $(n=6)$, Shigella spp. $(n=1)$, Enterobacter spp. $(n=1)$, and unknown Gram-negative bacteria $(n=1) .{ }^{2}$ Staphylococcus aureus $(n=3)$ and unknown Gram-positive bacteria $(n=13)$.

The laboratory findings of the BM patients are presented in Table 2. In brief, the median concentration of CRP was $161 \mathrm{mg} / \mathrm{L}$ and of leucocytes was $15.3 / \mu \mathrm{L}$ in the blood, while in the CSF, the concentration of glucose was $10 \mathrm{mg} / \mathrm{dL}$, of protein was $201 \mathrm{mg} / \mathrm{dL}$, of leucocytes was 1560/mm³ , and of MMP-8 was $854 \mathrm{ng} / \mathrm{mL}$.

\subsection{Association between Susceptability to BM and the Gene Polymorphisms of TLR4 and TLR9}

The frequencies of the studied TLR4 and TLR9 polymorphisms in the control group are presented in Table 3. Additionally, altogether, four subjects had another TLR4 polymorphism in the area of interest in the TLR4 gene. The frequency of the TLR4 rs201050092 (902T > C) minor genotype (CT) was 0.01 in both groups. When the HWE was calculated for TLR4 (rs4986790) and TLR9 (rs187084), no deviations were found in the control group $(p=0.099$ and $p=0.957)$ or in the patient group $(p=0.079$ and $p=0.931)$.

The frequency of the variant genotypes AG and GG in TLR4 was significantly higher in patients with $H$. influenzae meningitis than in the controls (OR, 2.5; 95\% CI, 1.2-5.4; $p=0.021$ ), whereas the frequency of the variant genotypes of CT and CC in TLR9 was significantly lower in patients with H. influenzae meningitis than in the controls (OR, 0.4; 95\% CI, 0.2-0.9; $p=0.036)$. No differences in the genotypes of TLR4 and TLR9 were found in patients with BM caused by other pathogens in comparison with the control children. The haplotype analyses between TLR4 and TLR9 did not show significant associations in patients with BM. 
Table 3. Genotype frequencies of the analyzed SNPs TLR4 rs4986790 (AA compared to AG and GG) and TLR9 rs187084 (TT compared to CT and CC) with the causative bacteria of bacterial meningitis (BM).

\begin{tabular}{|c|c|c|c|c|c|c|}
\hline & \multicolumn{3}{|c|}{ Gram-Negative Bacteria } & \multicolumn{2}{|c|}{ Gram-Positive Bacteria } & \multirow[b]{2}{*}{$\begin{array}{c}\text { Control } \\
\text { Group }\end{array}$} \\
\hline & H.Influenzae & N.Meningitidis & $\begin{array}{c}\text { Other } \\
\text { Bacteria }\end{array}$ & S.Pneumoniae & $\begin{array}{c}\text { Other } \\
\text { Bacteria }\end{array}$ & \\
\hline \multicolumn{7}{|l|}{ TLR4 } \\
\hline AA (\%) & $26(68.4)$ & $40(93.0)$ & $22(91.6)$ & $92(85.2)$ & $23(82.1)$ & $224(84.5)$ \\
\hline AG (\%) & $10(26.3)$ & $2(4.6)$ & $2(8.3)$ & $15(13.9)$ & $5(17.9)$ & $37(13.9)$ \\
\hline GG (\%) & $2(5.3)$ & $1(2.3)$ & 0 & $1(0.9)$ & 0 & $4(1.5)$ \\
\hline Total $n$ & 38 & 43 & 24 & 108 & 28 & 265 \\
\hline HWE & 0.44 & 0.002 & 0.831 & 0.661 & 0.604 & 0.099 \\
\hline$p$-Value ${ }^{1}$ & 0.022 & 0.164 & 0.549 & 0.999 & 0.784 & Ref. \\
\hline OR (95\% CI) & $2.5(1.2-5.4)$ & $0.4(0.1-1.4)$ & $0.5(0.11-2.2)$ & $1(0.5-1.7)$ & $1.2(0.43-3.3)$ & \\
\hline $\begin{array}{c}\text { TLR9 } \\
\text { rs187084 }\end{array}$ & & & & & & \\
\hline $\mathrm{TT}(\%)$ & $27(71.1)$ & $21(50.0)$ & $14(58.3)$ & $57(55.3)$ & $13(46.4)$ & $136(51.7)$ \\
\hline CT $(\%)$ & $8(21.1)$ & $20(47.6)$ & $9(37.5)$ & $45(43.7)$ & $13(46.4)$ & $106(40.3)$ \\
\hline CC $(\%)$ & $3(7.9)$ & $1(2.4)$ & $1(4.2)$ & $5(4.9)$ & $2(7.1)$ & $21(8.0)$ \\
\hline Total $n$ & 38 & 42 & 24 & 103 & 2 & 263 \\
\hline HWE & 0.065 & 0.133 & 0.764 & 0.296 & 0.572 & 0.957 \\
\hline$p$-Value & 0.036 & 0.869 & 0.670 & 0.819 & 0.692 & Ref. \\
\hline OR (95\% CI) & $0.4(0.2-0.9)$ & $1.1(0.6-2.1)$ & $0.76(0.33-1.8)$ & $0.9(0.6-1.5)$ & $1.2(0.57-2.7)$ & \\
\hline
\end{tabular}

${ }^{1}$ Bivariate analysis was calculated by Fisher exact test between BM and control group. OR, odds ratio; CI, confidence interval.

\subsection{Association between Laboratory Values, Severity Factors of BM, and the TLR4 and TLR9 Polymorphisms}

No associations were observed between the laboratory values or between the defined severity factors of BM and the studied SNPs across the entire study group. Table 4 shows the values from children who had meningitis caused by Gram-negative bacteria. The children who had meningitis caused by Gram-negative bacteria and who had a variant type of TLR4 had significantly lower levels of MMP-8 $(226 \mathrm{ng} / \mathrm{mL}$ (IQR, 64, 556) in their CFS at admission than those who had the AA genotype $(1133 \mathrm{ng} / \mathrm{mL}(\mathrm{IQR}, 834,1642) ; p=0.004)$. At the time of discharge, the children who carried a variant type of TLR4 had a higher risk of ataxia (adjusted OR, 12.91; 95\% Cl, 1.52-109.80; $p=0.019$ ) and other neurological sequelae (adjusted OR, 11.85; 95\% Cl, 1.07-131.49; $p=0.044$ ).

In the Gram-positive BM group, children who were carriers of a variant type of TLR4 (AG or GG) had lower levels of CSF glucose (7.5 mg/dL (IQR, 3.4, 12 03); $p=0.038$ ) and blood leukocytes $(9.5 / \mu \mathrm{L}$ $(\mathrm{IQR}, 5.06,17.30) ; p=0.024)$ at admission than those who had the AA genotype (Table S1).

A TLR9 variant genotype seemed to play a different role to a TLR4 variant type. In the bivariate analysis between the factors and TLR9 polymorphisms, carriers of a TLR9 variant genotype (CT or CC) had a lower risk of ataxia $(\mathrm{OR}, 0.22 ; 95 \% \mathrm{Cl}, 0.06-0.84 ; p=0.029)$ and other neurological sequelae (OR, $0.15 ; 95 \% \mathrm{Cl}, 0.02-1.26 ; p=0.049)$ at the time of discharge. After multivariate analysis, the differences were not statistically significant (Table 5). 
Table 4. Associations between the TLR4 (rs4986790) polymorphism and the laboratory values and severity factors of Gram-negative bacterial meningitis (BM).

\begin{tabular}{|c|c|c|c|c|}
\hline \multirow{2}{*}{ Clinical Features } & \multicolumn{2}{|c|}{$T L R 4$} & \multirow{2}{*}{ OR $(95 \% \mathrm{Cl})$} & \multirow{2}{*}{$p$-Value } \\
\hline & AA & AG and GG & & \\
\hline Poor general condition ${ }^{1}$ & $40(46.0)$ & $11(64.7)$ & $2.15(0.73-6.35)$ & 0.191 \\
\hline Convulsions during admission ${ }^{1}$ & $32(37.6)$ & $8(50.0)$ & $1.66(0.57-4.85)$ & 0.409 \\
\hline \multicolumn{5}{|l|}{ Level of consciousness ${ }^{1}$} \\
\hline Normal & $37(43.5)$ & $5(29.4)$ & - & \\
\hline Altered & $43(50.6)$ & $11(64.7)$ & - & 0.544 \\
\hline Coma & $5(5.9)$ & $1(5.9)$ & - & \\
\hline Glasgow coma score $(<12)^{1}$ & $31(38.3)$ & $9(56.3)$ & $2.07(0.70-6.14)$ & 0.266 \\
\hline Other focus of infection during hospital stay & $49(56.3)$ & $10(58.8)$ & $1.11(0.39-3.18)$ & 0.999 \\
\hline Pneumonia during hospital stay & $31(35.2)$ & $8(47.1)$ & $1.63(0.57-4.66)$ & 0.415 \\
\hline \multicolumn{5}{|l|}{ Outcome } \\
\hline Fatal & $15(17.0)$ & $6(35.3)$ & $2.66(0.85-8.30)$ & 0.102 \\
\hline Severe neurological sequelae ${ }^{3}$ & $5(6.9)$ & $2(18.2)$ & $2.98(0.50-17.68)$ & 0.231 \\
\hline Deafness $^{3}$ & $5(8.6)$ & $0(0.0)$ & $0.91(0.84-0.99)$ & 0.999 \\
\hline Blindness $^{3}$ & $1(1.4)$ & $2(20.0)$ & $\begin{array}{c}17.5(1.42-215.21) \\
-2\end{array}$ & $\begin{array}{c}0.039 \\
(0.99)^{2}\end{array}$ \\
\hline Any neurological sequelae (no ataxia) ${ }^{3}$ & $6(8.3)$ & $4(40.0)$ & $\begin{array}{c}7.33(1.31-33.41) \\
11.85(1.07-131.49)^{2}\end{array}$ & $\begin{array}{c}0.017 \\
(0.044)^{2}\end{array}$ \\
\hline Ataxia $^{3}$ & $12(16.9)$ & $7(70.0)$ & $\begin{array}{c}11.47(2.59-50.80) \\
12.91(1.52-109.80)^{2}\end{array}$ & $\begin{array}{c}0.001 \\
(0.019)^{2}\end{array}$ \\
\hline \multicolumn{5}{|l|}{ Laboratory variables, median (IQR) } \\
\hline $\mathrm{CRP}(\mathrm{mg} / \mathrm{L})$ & $\begin{array}{c}161.00 \\
(131.5, \\
172.0) \\
(n=77)\end{array}$ & $\begin{array}{c}160.00 \\
(70.5,161.0) \\
(n=13)\end{array}$ & - & 0.183 \\
\hline CSF glucose $^{1}(\mathrm{mg} / \mathrm{dL})$ & $\begin{array}{c}10.40 \\
(4.80 \\
22.10) \\
(n=88)\end{array}$ & $\begin{array}{c}9.30 \\
(5.15,26.63) \\
(n=16)\end{array}$ & - & 0.786 \\
\hline CSF protein ${ }^{1}(\mathrm{mg} / \mathrm{dL})$ & $\begin{array}{l}191.85 \\
(124.9, \\
257.15) \\
(n=46)\end{array}$ & $\begin{array}{l}187.05 \\
(146.48, \\
282.55) \\
(n=6)\end{array}$ & - & 0.748 \\
\hline CSF leukocytes ${ }^{1}\left(/ \mathrm{mm}^{3}\right)$ & $\begin{array}{l}1612.50 \\
(970.00, \\
3830.50) \\
(n=88)\end{array}$ & $\begin{array}{l}1440.00 \\
(857.50, \\
1440.00) \\
(n=17)\end{array}$ & - & 0.748 \\
\hline Blood leukocytes $(/ \mu \mathrm{L})$ & $\begin{array}{c}16.11 \\
(11.04 \\
24.35) \\
(n=73)\end{array}$ & $\begin{array}{c}13.96 \\
(8.23,22.20) \\
(n=12)\end{array}$ & - & 0.434 \\
\hline CSF MMP-8 ${ }^{1}(\mathrm{ng} / \mathrm{mL})$ & $\begin{array}{l}1132.57 \\
(834.04, \\
1641.75) \\
(n=30)\end{array}$ & $\begin{array}{c}225.93 \\
(63.56,556.31) \\
(n=6)\end{array}$ & - & 0.004 \\
\hline
\end{tabular}

${ }^{1}$ Determined/measured at admission. ${ }^{2}$ Determined at the time of discharge. ${ }^{3}$ Adjusted OR; binominal logistic regression analysis. Poor general condition, convulsions during admission, and weight below 2 SD were used as covariates. IQR, interquartile range (lower, upper); CRP, C-reactive protein; CSF, cerebrospinal fluid; MMP-8, matrix metalloproteinase-8. 
Table 5. Associations between the TLR9 (rs187084) polymorphism and the laboratory values and severity factors of Gram-negative bacterial meningitis.

\begin{tabular}{|c|c|c|c|c|}
\hline \multirow{2}{*}{ Clinical Features } & \multicolumn{2}{|c|}{ TLR9 } & \multirow{2}{*}{ OR $(95 \% \mathrm{Cl})$} & \multirow{2}{*}{$p$-Value } \\
\hline & TT & CT and CC & & \\
\hline Poor general condition ${ }^{1}$ & $28(45.9)$ & $23(54.8)$ & $1.43(0.65-3.14)$ & 0.426 \\
\hline Convulsions during admission ${ }^{1}$ & $28(46.7)$ & $12(30,0)$ & $0.490(0.21-1.14)$ & 0.144 \\
\hline \multicolumn{5}{|l|}{ Level of consciousness ${ }^{1}$} \\
\hline Normal & $25(41.7)$ & $17(41.5)$ & - & \\
\hline Altered & $31(51.7)$ & $22(53.7)$ & - & 0.928 \\
\hline Coma & $4(6.7)$ & $2(4.9)$ & - & \\
\hline Glasgow coma score $(<12)^{1}$ & $23(41.1)$ & $17(42.5)$ & $1.06(0.47-2.41)$ & 0.999 \\
\hline Other focus of infection during hospital stay & $35(57.4)$ & $23(54.8)$ & $0.90(0.41-1.99)$ & 0.841 \\
\hline Pneumonia during hospital stay & $24(38.7)$ & $15(35.7)$ & $0.88(0.39-1.98)$ & 0.838 \\
\hline \multicolumn{5}{|l|}{ Outcome } \\
\hline Fatal & $12(19.4)$ & $9(21.4)$ & $1.14(0.43-3.00)$ & 0.808 \\
\hline Severe neurological sequelae ${ }^{2}$ & $7(14.0)$ & $0(0.0)$ & $\begin{array}{c}0.86(0.77-0.96) \\
0.00(0.00-0.00)^{3}\end{array}$ & $\begin{array}{c}0.039 \\
0.999^{2}\end{array}$ \\
\hline Deafness ${ }^{2}$ & $3(7.7)$ & $2(7.4)$ & $0.96(0.15-6.17)$ & 0.999 \\
\hline Blindness $^{2}$ & $3(3.1)$ & $0(0.0)$ & $0.94(0.87-1.01)$ & 0.279 \\
\hline Any neurological sequelae (no ataxia) ${ }^{2}$ & $9(18.0)$ & $1(3.2)$ & $\begin{array}{c}0.15(0.02-1.26) \\
0.17(0.02-1.47)^{3}\end{array}$ & $\begin{array}{c}0.049 \\
(0.107)\end{array}$ \\
\hline Ataxia $^{2}$ & $16(32.7)$ & $3(9.7)$ & $\begin{array}{c}0.22(0.06-0.84) \\
0.25(0.06-1.04)^{2}\end{array}$ & $\begin{array}{c}0.029 \\
(0.057)^{2}\end{array}$ \\
\hline \multicolumn{5}{|l|}{ Laboratory variables, median (IQR) } \\
\hline $\mathrm{CRP}(\mathrm{mg} / \mathrm{L})$ & $\begin{array}{c}161.00 \\
(108.5,173.3) \\
(n=50)\end{array}$ & $\begin{array}{c}161.00 \\
(133.0,161.0) \\
(n=39)\end{array}$ & - & 0.814 \\
\hline CSF glucose $(\mathrm{mg} / \mathrm{dL})^{1}$ & $\begin{array}{c}8.75 \\
(4.73 \\
17.33) \\
(n=60)\end{array}$ & $\begin{array}{c}16.40 \\
(7.88,25.53) \\
(n=38)\end{array}$ & - & 0.252 \\
\hline CSF protein $(\mathrm{mg} / \mathrm{dL})^{1}$ & $\begin{array}{c}189.10 \\
(125.50, \\
275.00) \\
(n=31)\end{array}$ & $\begin{array}{c}189.40 \\
(131.15 \\
249.35) \\
(n=20)\end{array}$ & - & 0.549 \\
\hline CSF leukocytes $\left(/ \mathrm{mm}^{3}\right)^{1}$ & $\begin{array}{l}1518.50 \\
(850.00, \\
3125.00) \\
(n=62)\end{array}$ & $\begin{array}{l}1725.00 \\
(990.00, \\
5607.50) \\
(n=42)\end{array}$ & - & 0.991 \\
\hline Blood leukocytes $(/ \mu \mathrm{L})$ & $\begin{array}{c}15.74 \\
(10.89 \\
26.05) \\
(n=52)\end{array}$ & $\begin{array}{c}15.63 \\
(10.71,21.14) \\
(n=32)\end{array}$ & - & 0.826 \\
\hline CSF MMP-8 (ng/mL) median & $\begin{array}{l}958.28 \\
(319.46, \\
1496.89) \\
(n=20)\end{array}$ & $\begin{array}{l}1187.47 \\
(866.80, \\
1632.45) \\
(n=16)\end{array}$ & - & 0.278 \\
\hline
\end{tabular}

${ }^{1}$ Determined/measured at admission. ${ }^{2}$ Determined at the time of discharge. ${ }^{3}$ Adjusted OR; binominal logistic regression analysis. Poor general condition, convulsions during admission, and weight below 2 SD were used as covariates. IQR, interquartile range (lower, upper); CRP, C-reactive protein; CSF, cerebrospinal fluid; MMP-8, matrix metalloproteinase-8.

In the Gram-positive BM group, no differences were observed between the studied TLR9 SNPs, clinical features, and laboratory values (Table S2). 


\section{Discussion}

In the present study, we analyzed the frequencies of the different genotypes of two functional SNPs of TLR4 and TLR9 in Angolan children with BM caused by different bacteria, and we compared this to controls matched for age and ethnicity. We observed a significant difference between patients with BM caused by $H$. influenzae and the controls. In addition, patients with meningitis caused by Gram-negative bacteria who were carriers of a variant TLR4 genotype had an increased risk of ataxia and other neurological sequelae than those with a wild-type TLR4 genotype. To the best of our knowledge, this is the first study to show that genetic variation in TLR4 and TLR9 is associated with H. influenzae meningitis in Angolan children.

TLR4 SNP rs4986790 is one of the most studied SNPs and its variant genotypes AG and GG are associated with several infectious diseases. We recently reported that Finnish adults who are carriers of the variant genotypes of this TLR4 SNP had significantly lower concentrations of serum IL-6, IL-12, and IL-17A than those who are carriers of the wild-type of TLR4 [40]. It is known that TLR4 variants are associated with hypo-responsiveness to LPS, and humans with these polymorphisms are more susceptible to infections caused by Gram-negative bacteria, and the disease is often more severe [10]. One study found a connection between TLR4 SNPs and invasive pneumococcal sepsis [41]. Another study on survivors of meningococcal sepsis revealed an increased susceptibility between the TLR4 rs4986790 heterozygous mutation and N. meningitidis infection [30,42]. However, other studies have shown contradictory results [43-45].

The effect of the TLR9 SNP rs187084 has not yet been reported for pneumococcal or meningococcal infections, although it is associated with other bacterial infections. In puerperal women, an association between the TLR9 polymorphism and Streptococcus pyogenes has been observed [46]. The TLR9 polymorphism also has a functional significance in sepsis and multiple organ failure in patients with blunt trauma injury [47]. Furthermore, an association between persistent Streptococcus aureus nasal carriage and the TLR9 polymorphism has been found [48].

In this study, we found a correlation between the TLR4 and TLR9 polymorphisms and H. influenzae meningitis in Angolan children. This finding suggests that genetic variations of TLR4 rs4986790 and TLR9 rs187084 play a role in the susceptibility to $H$. influenzae meningitis. Moreover, the variant genotypes AG and GG of TLR4 rs4986790 are associated with increased susceptibility to H. influenzae meningitis. In contrast, the variant genotypes CT and CC of TLR9 rs187084 seem to decrease the susceptibility to $H$. influenzae meningitis. We observed no associations between the analyzed TLR4 and TLR9 polymorphisms with other BM-causing pathogens, such as S. pneumoniae and N. meningitidis.

We also compared the allele frequencies of TLR4 rs4986790 and TLR9 rs187084 with African and European populations. In this study, the major A and minor G allele frequencies of TLR4 rs4986790 in BM patients were 0.91 and 0.09 , which are similar to those observed in the African population (A, 0.93; G, 0.07) and the European population (A, 0.94; G, 0.06) in the 1000 Genomes Project [49]. However, when comparing the genotype frequencies (AA, 0.68; AG, 0.26; GG, 0.05) in patients with H. influenzae meningitis to the African population (AA, 0.87; AG, 0.12; GG, 0.009) and the European population (AA, 0.89; AG, 0.10; GG, 0.006), significant differences were found. These differences were only found in patients with BM caused by H. influenzae, but not by S. pneumoniae or N. meningitidis. In addition, there was no such observation in the controls of this study [49]. The major $\mathrm{T}$ and minor $\mathrm{G}$ allele frequencies of TLR9 rs187084 were 0.73 and 0.27 in BM patients, which are similar to the African population $(\mathrm{T}, 0.71 ; \mathrm{C}, 0.29)$ but different from other populations, such as the European population $(\mathrm{T}, 0.57 ; \mathrm{C}, 0.43)$. Although the genotype frequencies of TLR9 in patients with BM caused by all pathogens are similar to that in the African population (TT, 0.514; CT, 0.387; CC, 0.098) in the 1000 Genomes Project, a significant difference was found in patients with $H$. influenzae meningitis (TT, 0.711; CT, 0.211; CC, 0.079) [50].

One of the most important diagnostic tools in BM is CSF analysis. A confirmed diagnosis of BM can be made when the bacterial culture of CSF is positive. Low glucose and elevated leukocyte count, protein levels, and MMP-8 and -9 in CSF can indicate severe BM [51-53]. However, in this study, 
we observed no association between the analyzed SNPs and the levels of glucose, protein, or leukocytes in the CSF, or of CRP and leukocytes in the blood. In a previous study in Latin America, our group showed that elevated MMP-8 levels in CSF predict poor disease outcomes in BM caused by H. influenzae, N. meningitidis, and S. pneumoniae [52]. In this study, we observed that the variant types of TLR4 are associated with significantly lower levels of MMP-8 in children who had BM caused by Gram-negative bacteria, including H. influenzae and N. meningitidis. Since MMP-8 plays a central role in regulating tissue destruction, remodeling, and immune responses, this finding supports the broad role for the genetic variation of TLR4 in clinical outcomes of children with BM caused by Gram-negative bacteria.

In this study, patients who had meningitis caused by Gram-negative bacteria and who were carriers of the variant TLR4 genotypes had higher risk of ataxia and other neurological sequelae than those with the wild-type TLR4 genotype. More association and functional studies on the polymorphisms of TLRs are needed to reveal the exact mechanism causing the differences in clinical course and to obtain genetic traits that can be used for patient profiling and management of patients with a CNS infection.

Identifying the risk factors for severe disease has been, historically, the first step toward helping patients. If the risk cannot be eliminated (such as age) or manipulated (such as undernutrition), the next step is to identify the mechanisms by which a disease causes harm. By understanding the underlying pathophysiology, one might then search for better treatment options. For instance, if a disease causes an exaggerated innate immune response, then this can be targeted in order to improve the course and outcome of the disease.

There are some limitations of our study. Although the total number of confirmed BM patients was relatively large, the number of individual causative pathogens such as $H$. influenzae and N. meningitidis was limited. Therefore, it is possible that we could have missed some weak associations. In this study, only one SNP of TLR4 and TLR9 was tested, and the possible effects of the other SNPs in the two genes on the susceptibility to and outcome of bacterial meningitis should also be kept in mind. In addition, the possible influence of genetic drift from the enrolled population on the results cannot be completely excluded.

\section{Conclusions}

The polymorphisms of TLR4 rs4986790 (896A > G) and TLR9 $\mathrm{rs} 187084(-1486 \mathrm{~T}>\mathrm{C})$ were associated with susceptibility to $H$. influenzae meningitis in Angolan children. The variant genotypes of TLR4 seemed to be associated with an increased risk of $H$. influenzae meningitis, whereas the variant genotypes of TLR9 seemed to be associated with a decreased risk of H. influenzae meningitis. Furthermore, a variation in TLR4 may increase the risk of the development of certain neurological sequelae after BM caused by Gram-negative bacteria. However, we observed no correlation between the analyzed SNPs and the other causative pathogens of BM. It should be noted that these results are valid only for children in Angola.

Supplementary Materials: The following are available online at http:/www.mdpi.com/2073-4425/11/9/1099/s1, Table S1: Associations between the TLR4 polymorphism and the laboratory values and severity factors of Gram-positive bacterial meningitis; Table S2: Associations between the TLR9 polymorphism and the laboratory values and severity factors of Gram-positive bacterial meningitis.

Author Contributions: Conceptualization, I.R., T.P., and Q.H.; methodology, I.R., T.P., Q.H., E.T. and J.T.; formal analysis, E.T., J.T. and Q.H.; investigation, M.L.C., O.S., E.R. and T.P.; resources, T.P. and Q.H.; data curation, O.S., E.R. and T.P.; writing-original draft preparation, E.T., J.T. and Q.H.; writing-review and editing, M.L.C., O.S., E.R., I.R., T.P., Q.H., E.T. and J.T.; visualization, E.T., J.T. and Q.H.; supervision, I.R., T.P. and Q.H.; project administration, I.R. and T.P.; funding acquisition, T.P. and Q.H. All authors read and agreed to the published version of the manuscript.

Funding: This research was funded by the Päivikki and Sakari Sohlberg and the Paediatric Research Foundations, Helsinki, Finland.

Acknowledgments: The authors thank all participants and their guardians, the primary investigators, and their site staff.

Conflicts of Interest: The authors declare no conflict of interest. 


\section{References}

1. Paireau, J.; Chen, A.; Broutin, H.; Grenfell, B.; Basta, N.E. Seasonal dynamics of bacterial meningitis: A time-series analysis. Lancet Glob. Health 2016, 4, 370-377. [CrossRef]

2. Sanders, M.S.; van Well, G.T.J.; Ouburg, S.; Morré, S.A.; van Furth, A.M. Genetic variation of innate immune response genes in invasive pneumococcal and meningococcal disease applied to the pathogenesis of meningitis. Genes Immun. 2011, 12, 321-334. [CrossRef] [PubMed]

3. Zhang, P.; Zhang, N.; Liu, L.; Zheng, K.; Zhu, L.; Zhu, J.; Cao, L.; Jiang, Y.; Liu, G.; He, Q. Polymorphisms of toll-like receptors 2 and 9 and severity and prognosis of bacterial meningitis in Chinese children. Sci. Rep. 2017, 7, 42796. [CrossRef] [PubMed]

4. Weller, R.O.; Sharp, M.M.; Christodoulides, M.; Carare, R.O.; Møllgård, K. The meninges as barriers and facilitators for the movement of fluid, cells and pathogens related to the rodent and human CNS. Acta Neuropathol 2018, 135, 363-385. [CrossRef]

5. Pelkonen, T.; Roine, I.; Monteiro, L.; Correia, M.; Pitkäranta, A.; Bernardino, L.; Peltola, H. Risk Factors for Death and Severe Neurological Sequelae in Childhood Bacterial Meningitis in Sub-Saharan Africa. Clin. Infect. Dis 2009, 48, 1107-1110. [CrossRef]

6. Rodrigues, C.M.C.; Maiden, M.C.J. A world without bacterial meningitis: How genomic epidemiology can inform vaccination strategy. F1000Res 2018, 7. [CrossRef]

7. Saikia, K.K.; Das, B.K.; Bewal, R.K.; Kapil, A.; Arora, N.K.; Sood, S. Characterization of nasopharyngeal isolates of type b Haemophilus influenzae from Delhi. Indian J. Med. Res. 2012, 136, 855-861.

8. Weiser, J.N.; Ferreira, D.M.; Paton, J.C. Streptococcus pneumoniae: Transmission, colonization and invasion. Nat. Rev. Microbiol 2018, 16, 355-367. [CrossRef]

9. Heckenberg, S.G.B.; Brouwer, M.C.; van de Beek, D. Chapter 93. Bacterial meningitis. In Handbook of Clinical Neurology; Neurologic Aspects of Systemic Disease Part III; Biller, J., Ferro, J.M., Eds.; Elsevier: Amsterdam, The Netherlands, 2014; Volume 121, pp. 1361-1375.

10. Gowin, E.; Januszkiewicz-Lewandowska, D. Genes and their single nucleotide polymorphism involved in innate immune response in central nervous system in bacterial meningitis: Review of literature data. Inflamm. Res. 2018, 67, 655-661. [CrossRef]

11. Urtti, S.; Cruzeiro, M.L.; de Gouveia, L.; Peltola, H.; von Gottberg, A.; Kyaw, M.H.; Pelkonen, T. Surveillance of bacterial meningitis in an Angolan pediatric hospital after the introduction of pneumococcal conjugate vaccines. J. Glob. Health Rep. 2019, 3, e2019091. [CrossRef]

12. WHO/Number of Suspected Meningitis Cases and Deaths Reported. Available online: https://www.who. int/gho/epidemic_diseases/meningitis/suspected_cases_deaths_text/en/ (accessed on 29 January 2019).

13. Angola. Available online: https://www.gavi.org/programmes-impact/country-hub/africa/angola (accessed on 14 July 2020).

14. Peltola, H.; Pelkonen, T.; Bernardino, L.; Monteiro, L.; Silvestre, S. da C.; Anjos, E.; Cruzeiro, M.L.; Pitkäranta, A.; Roine, I. Vaccine-induced waning of Haemophilus influenzae Empyema and Meningitis, Angola. Emerg. Infect. Dis 2014, 20, 1887-1890. [CrossRef] [PubMed]

15. Malley, R.; Henneke, P.; Morse, S.C.; Cieslewicz, M.J.; Lipsitch, M.; Thompson, C.M.; Kurt-Jones, E.; Paton, J.C.; Wessels, M.R.; Golenbock, D.T. Recognition of pneumolysin by Toll-like receptor 4 confers resistance to pneumococcal infection. Proc. Natl Acad Sci USA 2003, 100, 1966-1971. [CrossRef] [PubMed]

16. Hanke, M.L.; Kielian, T. Toll-like receptors in health and disease in the brain: Mechanisms and therapeutic potential. Clin. Sci. 2011, 121, 367-387. [CrossRef] [PubMed]

17. Li, J.; Csakai, A.; Jin, J.; Zhang, F.; Yin, H. Therapeutic developments targeting oll-like receptor 4 mediated neuroinflammation. ChemMedChem 2016, 11, 154-165. [CrossRef] [PubMed]

18. Moresco, E.M.Y.; LaVine, D.; Beutler, B. Toll-like receptors. Curr. Biol. 2011, 21, R488-R493. [CrossRef]

19. Kuzmich, N.N.; Sivak, K.V.; Chubarev, V.N.; Porozov, Y.B.; Savateeva-Lyubimova, T.N.; Peri, F. TLR4 Signaling pathway modulators as potential therapeutics in inflammation and sepsis. Vaccines 2017, 5, 34. [CrossRef]

20. Zhang, Z.; Ohto, U.; Shimizu, T. Toward a structural understanding of nucleic acid-sensing Toll-like receptors in the innate immune system. FEBS Lett. 2017, 591, 3167-3181. [CrossRef] 
21. Mogensen, T.H.; Paludan, S.R.; Kilian, M.; Østergaard, L. Live Streptococcus pneumoniae, Haemophilus influenzae, and Neisseria meningitidis activate the inflammatory response through Toll-like receptors 2, 4, and 9 in species-specific patterns. J. Leukocyte Biol. 2006, 80, 267-277. [CrossRef]

22. Skevaki, C.; Pararas, M.; Kostelidou, K.; Tsakris, A.; Routsias, J.G. Single nucleotide polymorphisms of Toll-like receptors and susceptibility to infectious diseases: TLR SNPs and infectious diseases. Clin. Exp. Immunol. 2015, 180, 165-177. [CrossRef]

23. Long, H.; O'Connor, B.P.; Zemans, R.L.; Zhou, X.; Yang, I.V.; Schwartz, D.A. The Toll-Like Receptor 4 Polymorphism Asp299Gly but Not Thr399Ile Influences TLR4 Signaling and Function. PLoS ONE 2014, 9, e093550. [CrossRef]

24. Teräsjärvi, J.T.; Toivonen, L.; Vuononvirta, J.; Mertsola, J.; Peltola, V.; He, Q. TLR4 Polymorphism, Nasopharyngeal Bacterial Colonization, and the development of childhood asthma: A prospective birth-cohort study in Finnish children. Genes 2020, 11, 768. [CrossRef] [PubMed]

25. Lorenz, E.; Mira, J.P.; Frees, K.L.; Schwartz, D.A. Relevance of mutations in the TLR4 receptor in patients with gram-negative septic shock. Arch. Intern. Med. 2002, 162, 1028-1032. [CrossRef]

26. Tulic, M.K.; Hurrelbrink, R.J.; Prêle, C.M.; Laing, I.A.; Upham, J.W.; Souef, P.L.; Sly, P.D.; Holt, P.G. TLR4 Polymorphisms mediate impaired responses to respiratory syncytial virus and lipopolysaccharide. J. Immunol. 2007, 179, 132-140. [CrossRef] [PubMed]

27. Barber, R.C.; Aragaki, C.C.; Rivera-Chavez, F.A.; Purdue, G.F.; Hunt, J.L.; Horton, J.W. TLR4 and TNF- $\alpha$ polymorphisms are associated with an increased risk for severe sepsis following burn injury. J. Med. Genet. 2004, 41, 808-813. [CrossRef]

28. Brouwer, M.C.; de Gans, J.; Heckenberg, S.G.; Zwinderman, A.H.; van der Poll, T.; van de Beek, D. Host genetic susceptibility to pneumococcal and meningococcal disease: A systematic review and meta-analysis. Lancet Infect. Dis. 2009, 9, 31-44. [CrossRef]

29. Allen, A.; Obaro, S.; Bojang, K.; Awomoyi, A.A.; Greenwood, B.M.; Whittle, H.; Sirugo, G.; Newport, M.J. Variation in Toll-like receptor 4 and susceptibility to group a meningococcal meningitis in Gambian children. Pediatric Infect. Dis. J. 2003, 22, 1018. [CrossRef] [PubMed]

30. Gowin, E.; Świątek-Kościelna, B.; Kałużna, E.; Nowak, J.; Michalak, M.; Wysocki, J.; Januszkiewicz-Lewandowska, D. Analysis of TLR2, TLR4, and TLR9 single nucleotide polymorphisms in children with bacterial meningitis and their healthy family members. Int. J. Infect. Dis. 2017, 60, 23-28. [CrossRef]

31. Tian, S.; Zhang, L.; Yang, T.; Wei, X.; Zhang, L.; Yu, Y.; Li, Y.; Cao, D.; Yang, X. The Associations between Toll-Like Receptor 9 Gene Polymorphisms and Cervical Cancer Susceptibility. Mediat. Inflamm. 2018, 2018, 9127146. [CrossRef]

32. Gębura, K.; Świerkot, J.; Wysoczańska, B.; Korman, L.; Nowak, B.; Wiland, P.; Bogunia-Kubik, K. Polymorphisms within Genes Involved in Regulation of the NF-kB Pathway in Patients with Rheumatoid Arthritis. Int. J. Mol. Sci. 2017, 18, 1432. [CrossRef]

33. Bharti, D.; Kumar, A.; Mahla, R.S.; Kumar, S.; Ingle, H.; Shankar, H.; Joshi, B.; Raut, A.A.; Kumar, H. The role of TLR9 polymorphism in susceptibility to pulmonary tuberculosis. Immunogenetics 2014, 66, 675-681. [CrossRef]

34. van Well, G.T.J.; Sanders, M.S.; Ouburg, S.; van Furth, A.M.; Morré, S.A. Polymorphisms in Toll-Like Receptors 2, 4, and 9 Are Highly Associated with Hearing Loss in Survivors of Bacterial Meningitis. PLoS ONE. 2012, 7, e35837. [CrossRef]

35. Sanders, M.S.; van Well, G.T.J.; Ouburg, S.; Lundberg, P.S.J.; van Furth, A.M.; Morré, S.A. Single Nucleotide Polymorphisms in TLR9 Are Highly Associated with Susceptibility to Bacterial Meningitis in Children. Clin. Infect. Dis 2011, 52, 475-480. [CrossRef] [PubMed]

36. Pelkonen, T.; Roine, I.; Cruzeiro, M.L.; Pitkäranta, A.; Kataja, M.; Peltola, H. Slow initial $\beta$-lactam infusion and oral paracetamol to treat childhood bacterial meningitis: A randomised, controlled trial. Lancet Infect. Dis. 2011, 11, 613-621. [CrossRef]

37. Savonius, O.; Rugemalira, E.; Roine, I.; Cruzeiro, M.L.; Peltola, H.; Pelkonen, T. Extended Continuous $\beta$-Lactam Infusion with Oral Acetaminophen in Childhood Bacterial Meningitis: A Randomized, Double-Blind Clinical Trial. Clin. Infect. Dis. 2020. [CrossRef] 
38. Pelkonen, T.; Roine, I.; Monteiro, L.; Simões, M.J.; Anjos, E.; Pelerito, A.; Pitkäranta, A.; Bernardino, L.; Peltola, H. Acute childhood bacterial meningitis in Luanda, Angola. Scand. J. Infect. Dis. 2008, 40, 859-866. [CrossRef] [PubMed]

39. Teräsjärvi, J.; Hakanen, A.; Korppi, M.; Nuolivirta, K.; Gröndahl-Yli-Hannuksela, K.; Mertsola, J.; Peltola, V.; $\mathrm{He}, \mathrm{Q}$. Rapid detection of functional gene polymorphisms of TLRs and IL-17 using high resolution melting analysis. Sci. Rep. 2017, 7. [CrossRef]

40. Korppi, M.; Teräsjärvi, J.; Lauhkonen, E.; Huhtala, H.; Nuolivirta, K.; He, Q. Toll-like receptor 4 polymorphisms were associated with low serum pro-inflammatory cytokines in BCG osteitis survivors. Acta Paediatr. 2019. [CrossRef]

41. Yuan, F.F.; Marks, K.; Wong, M.; Watson, S.; de Leon, E.; McIntyre, P.B.; Sullivan, J.S. Clinical relevance of TLR2, TLR4, CD14 and Fc $\gamma$ RIIA gene polymorphisms in Streptococcus pneumoniae infection. Immunol. Cell Biol. 2008, 86, 268-270. [CrossRef]

42. Smirnova, I.; Mann, N.; Dols, A.; Derkx, H.H.; Hibberd, M.L.; Levin, M.; Beutler, B. Assay of locus-specific genetic load implicates rare Toll-like receptor 4 mutations in meningococcal susceptibility. PNAS 2003, 100, 6075-6080. [CrossRef]

43. Moens, L.; Verhaegen, J.; Pierik, M.; Vermeire, S.; De Boeck, K.; Peetermans, W.E.; Bossuyt, X. Toll-like receptor 2 and Toll-like receptor 4 polymorphisms in invasive pneumococcal disease. Microbes Infect. 2007, 9, 15-20. [CrossRef]

44. Read, R.C.; Pullin, J.; Gregory, S.; Borrow, R.; Kaczmarski, E.B.; di Giovine, F.S.; Dower, S.K.; Cannings, C.; Wilson, A.G. A functional polymorphism of toll-like receptor 4 Is not associated with likelihood or severity of eningococcal Disease. J. Infect. Dis 2001, 184, 640-642. [CrossRef]

45. Biebl, A.; Muendlein, A.; Kazakbaeva, Z.; Heuberger, S.; Sonderegger, G.; Drexel, H.; Lau, S.; Nickel, R.; Kabesch, M.; Simma, B. CD14 C-159T and Toll-Like Receptor 4 Asp299Gly Polymorphisms in surviving Meningococcal Disease patients. PLoS ONE 2009, 4, e7374. [CrossRef]

46. Davis, S.M.; Clark, E.A.S.; Nelson, L.T.; Silver, R.M. The association of innate immune response gene polymorphisms and puerperal group A streptococcal sepsis. Am. J. Obstet. Gynecol. 2010, 202, 308.e1-308.e8. [CrossRef] [PubMed]

47. Chen, K.-H.; Zeng, L.; Gu, W.; Zhou, J.; Du, D.-Y.; Jiang, J.-X. Polymorphisms in the toll-like receptor 9 gene associated with sepsis and multiple organ dysfunction after major blunt trauma. BJS (Br. J. Surg.) 2011, 98, 1252-1259. [CrossRef] [PubMed]

48. Nurjadi, D.; Heeg, K.; Weber, A.N.R.; Zanger, P. Toll-like receptor 9 (TLR-9) promotor polymorphisms and gene expression are associated with persistent Staphylococcus aureus nasal carriage. Clin. Microbiol. Infect. 2018, 24, 1210.e7-1210.e12. [CrossRef]

49. rs4986790 (SNP). Population Genetics. Homo Sapiens. Ensembl Genome Browser 98. Available online: http://www.ensembl.org/Homo_sapiens/Variation/Population?db=core;r=9:117712524-117713524; $\mathrm{v}=\mathrm{rs} 4986790 ; \mathrm{vdb}=$ variation; $\mathrm{vf}=152699755$ (accessed on 17 December 2019).

50. rs187084 (SNP). Population Genetics. Homo Sapiens. Ensembl Genome Browser 98. Available online: http://www.ensembl.org/Homo_sapiens/Variation/Population?db=core;r=3:52226515-52227515;v= rs187084; vdb=variation;vf=37101106 (accessed on 17 December 2019).

51. Nigrovic, L.E.; Kimia, A.A.; Shah, S.S.; Neuman, M.I. Relationship between Cerebrospinal Fluid Glucose and Serum Glucose. N. Eng. J. Med. 2012, 366, 576-578. [CrossRef]

52. Savonius, O.; Roine, I.; Alassiri, S.; Tervahartiala, T.; Helve, O.; Fernández, J.; Peltola, H.; Sorsa, T.; Pelkonen, T. The Potential Role of Matrix Metalloproteinases 8 and 9 and Myeloperoxidase in Predicting Outcomes of Bacterial MENINGITIS of Childhood. Available online: https://www.hindawi.com/journals/mi/2019/7436932/ (accessed on 25 May 2020).

53. Leppert, D.; Leib, S.L.; Grygar, C.; Miller, K.M.; Schaad, U.B.; Holländer, G.A. Matrix Metalloproteinase (MMP)-8 and MMP-9 in Cerebrospinal fluid during Bacterial Meningitis: Association with blood-brain barrier damage and Neurological Sequelae. Clin. Infect. Dis. 2000, 31, 80-84. [CrossRef]

(C) 2020 by the authors. Licensee MDPI, Basel, Switzerland. This article is an open access article distributed under the terms and conditions of the Creative Commons Attribution (CC BY) license (http://creativecommons.org/licenses/by/4.0/). 